Article

\title{
Bisphenol A Activates Calcium Influx in Immortalized GnRH Neurons
}

\author{
Federico Alessandro Ruffinatti ${ }^{1}, *\left(\mathbb{D}\right.$, Alessandra Gilardino ${ }^{2}$, Valter Secchi ${ }^{2}$, Erika Cottone ${ }^{2}$, \\ Davide Lovisolo $^{2}$ and Patrizia Bovolin ${ }^{2}$ \\ 1 Department of Pharmaceutical Sciences, University of Eastern Piedmont, via Bovio 6, 28100 Novara, Italy \\ 2 Department of Life Sciences and Systems Biology, University of Torino, via Accademia Albertina 13, \\ 10123 Torino, Italy; alessandra.gilardino@unito.it (A.G.); valter.secchi@studenti.unito.it (V.S.); \\ erika.cottone@unito.it (E.C.); davide.lovisolo@unito.it (D.L.); patrizia.bovolin@unito.it (P.B.) \\ * Correspondence: federicoalessandro.ruffinatti@uniupo.it
}

Received: 20 March 2019; Accepted: 26 April 2019; Published: 1 May 2019

\begin{abstract}
Bisphenol A (BPA) is one of the most widely used chemicals worldwide, e.g., as a component of plastic containers for food and water. It is considered to exert an estrogenic effect, by mimicking estradiol (E2) action. Because of this widespread presence, it has attracted the interest and concern of researchers and regulators. Despite the vast amount of related literature, the potential adverse effects of environmentally significant doses of BPA are still object of controversy, and the mechanisms by which it can perturb endocrine functions, and particularly the neuroendocrine axis, are not adequately understood. One of the ways by which endocrine disruptors (EDCs) can exert their effects is the perturbation of calcium signaling mechanisms. In this study, we addressed the issue of the impact of BPA on the neuroendocrine system with an in vitro approach, using a consolidated model of immortalized Gonadotropin-Releasing Hormone (GnRH) expressing neurons, the GT1-7 cell line, focusing on the calcium signals activated by the endocrine disruptor. The investigation was limited to biologically relevant doses (nM- $\mu \mathrm{M}$ range). We found that BPA induced moderate increases in intracellular calcium concentration, comparable with those induced by nanomolar doses of E2, without affecting cell survival and with only a minor effect on proliferation.
\end{abstract}

Keywords: bisphenol A; endocrine disruptors; calcium signaling; neuroendocrine cells; estradiol

\section{Introduction}

Among the many chemical molecules present in the environment that can interact with the endocrine system and have been classified as endocrine disruptors, Bisphenol A (BPA) is one of the most widely used, e.g., as a component of plastic containers for food and water. It is considered to exert an estrogenic effect, by mimicking estradiol (E2) action [1,2]. Low levels of BPA have been found in more than $90 \%$ of urine samples from human subjects in the US [3,4] and in about $50 \%$ of samples of milk from lactating women [5]. Because of this widespread presence, it has attracted the interest and concern of researchers and regulators, and a huge amount of studies has addressed its potential adverse effects. Despite this, the field is still open to controversy. There is a strong agreement on the levels of BPA that can be found in humans [2,3,5-8]: most reports converge on the range $0.3-10 \mathrm{ng} / \mathrm{mL}$ (i.e., nanomolar concentrations). On the other hand, BPA effects registered by the epidemiological studies are less univocal, in particular when dealing with potential neurological damages. Recently, a relationship between children exposure to several environmental toxicants, including BPA, and autism spectrum disorders has been proposed [9], but the evidence is limited. Several reviews dealing with data from humans have recently been published, some of them focusing specifically on effects on the nervous system $[8,10-13]$. Most of these reviews point to the limitations and inconsistencies of the 
available data, and on the difficulty to conciliate the limited information on humans with the findings from animal studies. As for the latter, and restricting to studies on effects on the nervous system, several groups have reported loss of synaptic contacts and plasticity, alterations in neuronal development and morphology in rodents [14-18] and fishes [19], and impairment of visual function in cats [20]. Of particular relevance, given the differences in metabolism and physiology of estrogens between rodents and primates, are the data reporting a loss of synaptic contacts in the monkey prefrontal cortex and hippocampus [21].

In vitro data referring to effects on neuronal models are even more scarce: a reduction in the differentiation of human stem cells into dopaminergic neurons has been reported [22]; and another study has reported effects on gene transcription in Gonadotropin-Releasing Hormone $(\mathrm{GnRH})$ neurons and GT1-7 cells [23]. In the latter experimental model, BPA has been shown to induce oxidative stress [24].

The main bias that affects the animal and in vitro data is the extremely wide range of concentrations administered to animals or used in vitro. It has been shown that administration of $25 \mu \mathrm{g} / \mathrm{kg}$ to pregnant rats resulted in blood levels in the $\mathrm{ng} / \mathrm{mL}$ range, i.e., the range reported in humans [6]. The current US-Environmental Protection Agency (EPA) reference dose (the daily dose that EPA calculates to be safe for humans over the lifetime) is $50 \mu \mathrm{g} / \mathrm{kg} /$ day [2]. However, adverse effects have been reported for lower doses, and, on the contrary, many of the data found in the literature are obtained at significantly higher doses $[15,16,23,24]$, thus hindering their functional relevance. A further complication is due to the finding that the effects at low doses may be quite different, and even stronger, than those observed at higher concentrations [16,25]. As reported by a consensus panel [6]: "exposing tissues to only an extremely narrow range of doses of BPA may lead to erroneous conclusions ... animal experiments on unstudied systems must avoid narrow dose ranges, especially the use of only a few very high doses".

The field is therefore quite open, and while better designed studies on humans are quite unanimously considered of the utmost importance, the understanding and clarification of the mechanisms by which biologically realistic doses of BPA can exert potential interference with the endocrine and neuroendocrine systems is of high relevance. Interestingly, a large-scale cooperative project headed in the US by the NIEHS and FDA is currently operative [26], with the aim of collecting controlled and reproducible animal data using doses ranging from 2.5 to $25,000 \mu \mathrm{g} / \mathrm{kg} /$ day, i.e., exposures corresponding to blood levels from $\mathrm{nM}$ to $\mu \mathrm{M}$ concentrations.

Even if the hypothalamic-pituitary axis is the main controller of reproductive function, the data on the effects of BPA on GnRH neurons are quite limited. In addition to the two papers cited above [23,24], a few papers [27-29] point to indirect effects through kisspeptin neurons and consequent altered input on GnRH neurons; but here again the range of doses is quite wide. Another paper [30] reports no significant change in neuronal morphology and inputs at the US-EPA reference dose; it only exacerbated responses normally induced by E2. Finally, it has been found that, in rats, neonatal exposure to BPA affected ovarian development but not the ability of GnRH neurons to respond to steroid-positive feedback [31]. Therefore, to date, the data about the effects of low, environmentally relevant doses on GnRH neurons are far from complete.

One of the ways by which endocrine disruptors (EDCs) can exert their effects is the perturbation of calcium signaling mechanisms. Several calcium permeable channels have been reported to be affected by BPA exposure [32], both by changes in protein expression and by direct activation/inhibition mechanisms. Most data refer to non-neuronal models, and report different and in some cases conflicting effects, which apparently depend on the cellular model and doses used (up to hundreds of $\mu \mathrm{M}$, see, e.g., [33]). For neuronal and neuroendocrine models, where the calcium signaling machinery is the key controller of hormone secretion, the data are quite limited, and again not univocal. Block of voltage-dependent calcium channels (VDCCs) in different cell types, including neurons, at EC $_{50}$ values of 26-35 $\mu \mathrm{M}$ has been reported [34]. On the contrary, doses above $100 \mu \mathrm{M}$ induced an increase in the intracellular calcium concentration, $\left[\mathrm{Ca}^{2+}\right]_{i}$, in a hippocampus-derived cell line [35]. At more environmentally relevant doses (10-100 nM), BPA increased the calcium transients elicited by activation 
of NMDARs in a subpopulation (less than 10\%) of primary hippocampal neurons [36]. In the pituitary cell line GH3, BPA in the nM range induces calcium oscillations comparable to those elicited by E2 [37]. Another group reported a reduction in spontaneous calcium oscillations in migrating $\mathrm{GnRH}$ neurons from nasal explants [38], but most effects were observed at a high dose $(50 \mu \mathrm{g} / \mathrm{mL})$.

We addressed the issue of the impact of BPA on the neuroendocrine system with an in vitro approach, using a consolidated model of immortalized GnRH neurons, the GT1-7 cell line, focusing our attention on the calcium signals activated by the endocrine disruptor and on the mechanisms involved, and limiting the investigation to biologically relevant doses (nM- $\mu \mathrm{M}$ range).

\section{Results}

\subsection{Effects of BPA on Proliferation of GT1-7 Cells}

Since it has been reported that BPA can alter cell cycle progression in endocrine cells [39], we tested the effects of a range of concentrations (from $10 \mathrm{nM}$ to $5 \mu \mathrm{M}$ ) of the molecule on GT1-7 cells maintained in $10 \%$ FBS for 24 and $72 \mathrm{~h}$.

Figure $1 \mathrm{a}$ shows that both at 24 and $72 \mathrm{~h}$ in culture BPA induced a significant but limited (about $10 \%$ increase in the proliferative rate at all doses. Thus, the molecule only minimally affects cell cycle progression in the range usually considered to be relevant for animals and humans. Moreover, since the slight increase in number of cells could mask a combined positive effect on proliferative rate with a negative one on cell survival, we tested the effect of BPA on cells kept for $24 \mathrm{~h}$ in the presence of $0.5 \%$ FBS, a condition that promotes cell survival without significantly increasing cell proliferation. In these conditions, no significant difference in cell number could be observed between control and BPA-treated cells (Figure 1b).

a
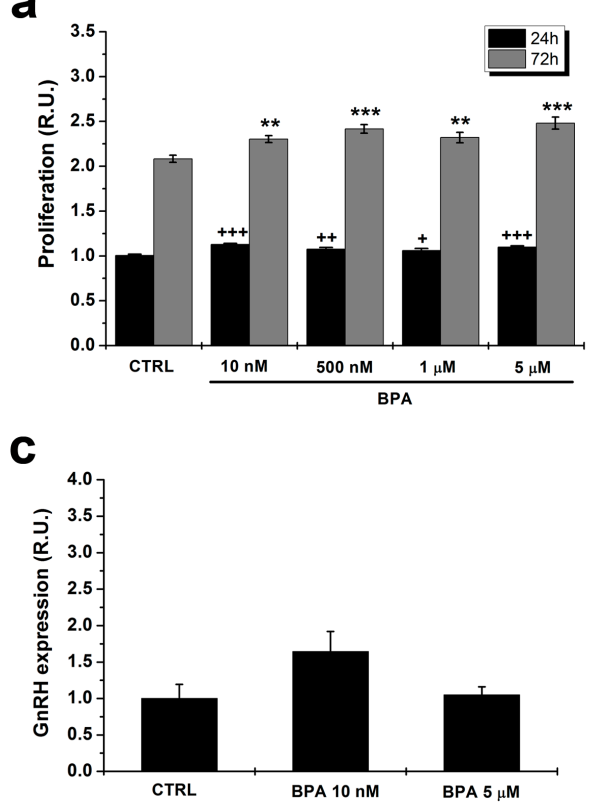

b

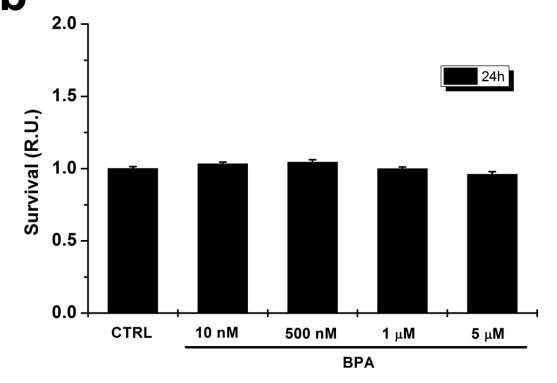

Figure 1. Effects of BPA concentrations in the $\mathrm{nM}-\mu \mathrm{M}$ range on proliferation and survival of GT1-7 cells. (a) BPA induced a limited but statistically significant increase in cell proliferation in a concentration-independent way, at both 24 and $72 \mathrm{~h}$. ANOVA and Dunnett's post hoc test; ${ }^{*} p<0.05,{ }^{* *} p<0.01,{ }^{* * *} p<0.001$ for each BPA dose vs. control condition (CTRL) at $24 \mathrm{~h} ;+p<0.05$, $++p<0.01,+++p<0.001$ for each BPA dose vs. CTRL at $72 \mathrm{~h}$. (b) The same concentration range had no effect on cell survival at $24 \mathrm{~h}$ (ANOVA and Dunnett's post hoc test). (c) At both $10 \mathrm{nM}$ and $5 \mu \mathrm{M}$, BPA did not significantly affect GnRH expression ( $p=0.15$; ANOVA and Dunnett's post hoc test). R.U., Relative Units with respect to the control condition (CTRL). 


\subsection{BPA Does Not Affect GnRH Expression}

Since GnRH expression is a key functional marker of GT1-7 cells, we investigated whether BPA affects this parameter by means of quantitative RT-PCR. As shown in Figure 1c, at both $10 \mathrm{nM}$ and $5 \mu \mathrm{M}$ the levels of gene expression were not significantly altered as compared with control cells.

\subsection{BPA Induces Changes in $\left[\mathrm{Ca}^{2+}\right]_{i}$}

Next, we looked at the effects of BPA, in the same concentration range, on intracellular calcium homeostasis, a key parameter in the control of neuroendocrine cell function.

BPA induced dose-dependent changes in the intracellular calcium concentration, $\left[\mathrm{Ca}^{2+}\right]_{\mathrm{i}}$. In particular, four different BPA concentrations (10 nM, $200 \mathrm{nM}, 1 \mu \mathrm{M}$ and $5 \mu \mathrm{M})$ were tested in $m$ independent experiments ( $m$ depending on the particular BPA dose, ranging from $m=6$ to $m=11$, for a total number of recorded cells ranging from $n=350$ to $n=902$ ). The left panel of Figure 2a-d shows examples of average responses at the four different doses; examples of responses from individual cells are shown on the right. In the presence of BPA, average responses were in most cases sustained and long lasting, showing a plateau; at the lower doses, the responses were partially reversible following washout of the agonist (Figure 2a-c). On the contrary, at $5 \mu \mathrm{M}$, the response was in most cases sustained even after washing (Figure 2d).

In four experiments, cells were challenged with incremental doses ( 1 and $5 \mu \mathrm{M})$; in two of them, the higher dose induced a further increase in $\left[\mathrm{Ca}^{2+}\right]_{i}$ levels (Figure 2e). In this case, partial reversibility after washing was observed.
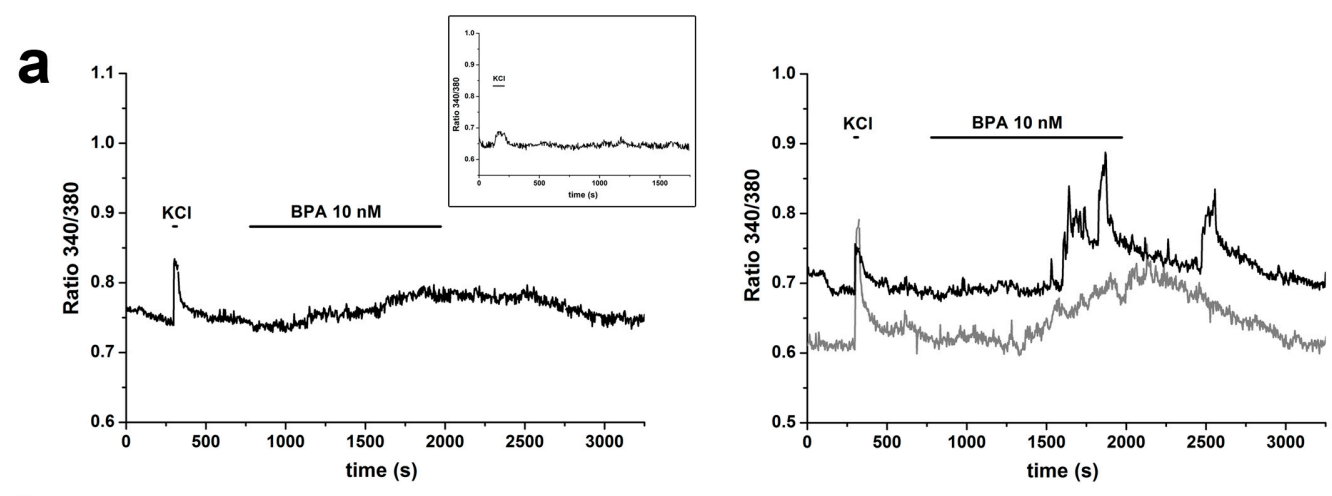

b

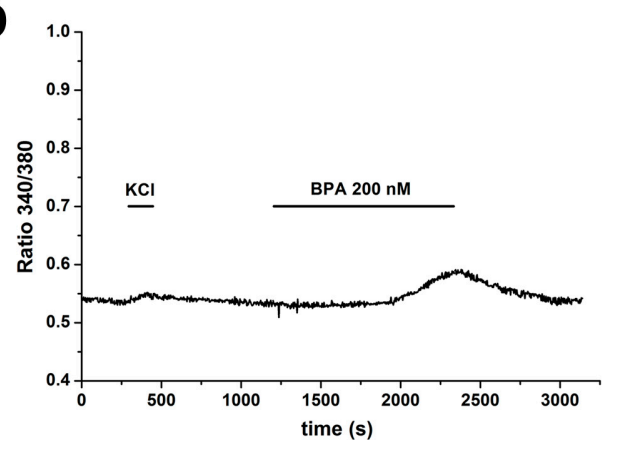

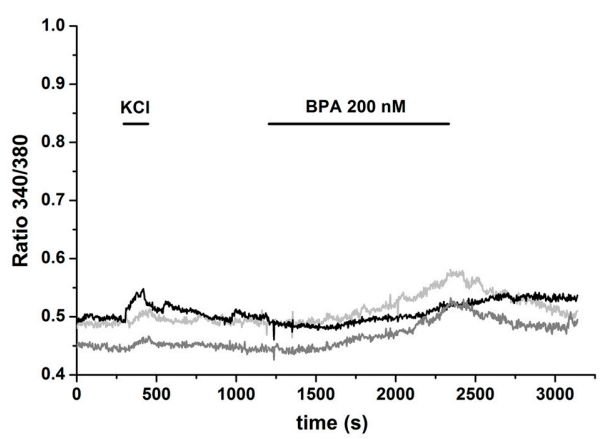

Figure 2. Cont. 

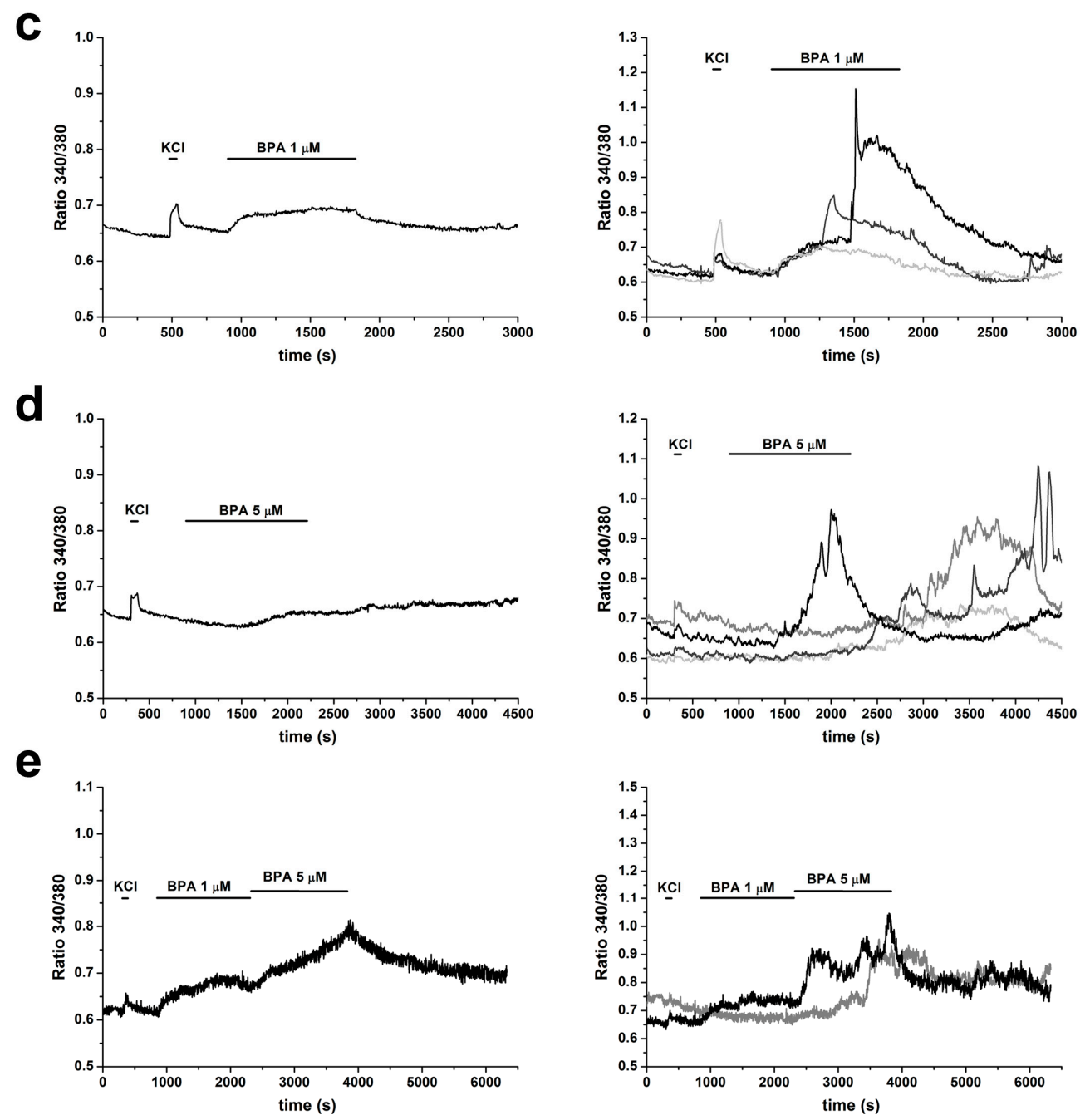

Figure 2. BPA-induced increases in cytosolic calcium concentration. (a-d) Changes in $\left[\mathrm{Ca}^{2+}\right]_{\mathrm{i}}$ in response to $10 \mathrm{nM}, 200 \mathrm{nM}, 1 \mu \mathrm{M}$ and $5 \mu \mathrm{M}$ BPA, respectively. (Left) Averaged responses from all cells from a single experiment. (Right) Examples of responses form single cells. Before the application of BPA, cells were chemically depolarized with $40 \mathrm{mM} \mathrm{KCl}$ and the increase in $\left[\mathrm{Ca}^{2+}\right]_{\mathrm{i}}$ due to influx through voltage-dependent channels was recorded. (e) Responses to incremental doses of BPA: (Left) averaged responses; and (Right) representative responses of individual cells. Inset in (a): averaged trace from $n=55$ cells maintained for $30 \mathrm{~min}$ in normal physiological solution.

The percentage of responding cells increased significantly and monotonically (from $27 \%$ to $79 \%$ ) with BPA concentration (Figure 3a); the peak amplitude of the response also followed a similar dose-dependent trend, with $\Delta R / R$ ranging from $0.12 \pm 0.01$ to $0.29 \pm 0.01$ (Figure $3 b$ ).

A marked heterogeneity was present in the time course of the increases in $\left[\mathrm{Ca}^{2+}\right]_{\mathrm{i}}$ : latencies and slope of rise of averaged responses showed a high degree of variability at all four concentrations tested. When analyzed at the single cell level, the heterogeneity was even more marked, even within the same experiment, as can be seen in the right panels of Figure 2a-d. In some cells, the responses started even after washout of the agonist. 

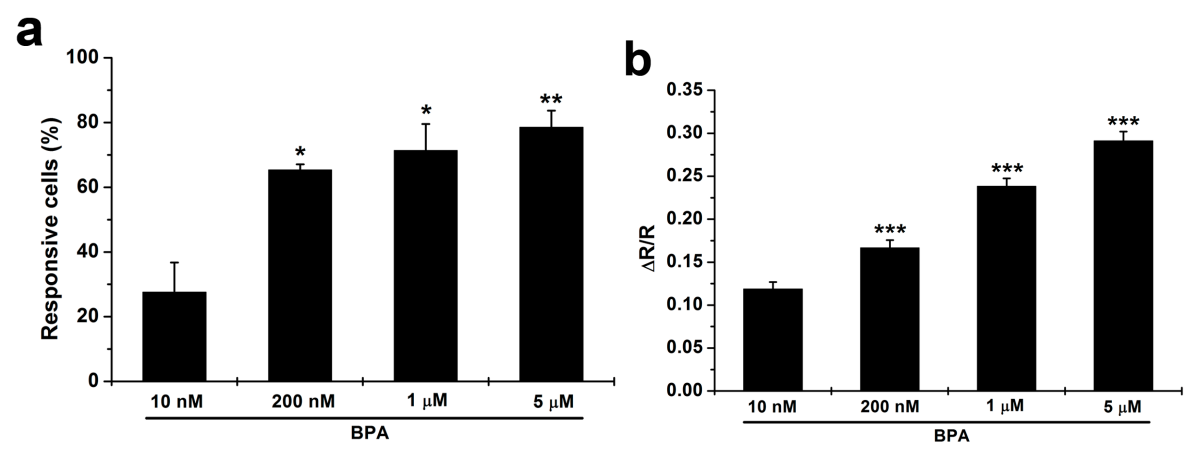

Figure 3. Both number of responding cells and amplitude of response were dependent on BPA concentration. (a) Percentage of responsive cells. Total cell number for each condition was $n=434$ at 10 $\mathrm{nM}, n=350$ at $200 \mathrm{nM}, n=713$ at $1 \mu \mathrm{M}, n=902$ at $5 \mu \mathrm{M}$. Welch's F-test and Games-Howell post hoc test; ${ }^{*} p<0.05,{ }^{* *} p<0.01$ for each BPA dose vs. the lowest one (10 nM). (b) Response peak amplitudes. Total number of responsive cells for each condition was $n=116$ at $10 \mathrm{nM}, n=229$ at $200 \mathrm{nM}, n=543$ at $1 \mu \mathrm{M}, n=729$ at $5 \mu \mathrm{M}$. Kruskal-Wallis $H$-test and Dunn's post hoc test; ${ }^{* * *} p<0.001$ for all the possible pairwise comparisons.

In addition, the data presented on the right side of Figure 2 provide evidence that, at the single cell level, an oscillatory behavior could be observed in a limited percentage of the responsive cells. The percentage was not significantly different at all concentrations (mean values: $20 \%, 11 \%, 9 \%$, and $10 \%$ at the four tested doses, respectively), even if in some experiments with stimulation by incremental doses the oscillatory behavior was present in some cells only at the higher dose tested (Figure 2e, right).

The increases in $\left[\mathrm{Ca}^{2+}\right]_{\mathrm{i}}$ were totally dependent on influx from the extracellular medium, as shown in Figure $4 \mathrm{a}$ (one experiment representative of $m=4$ ). To provide information on the channels involved in the generation of this influx, we performed three experiments ( $n=140$ cells; only cells that gave a response to $\mathrm{KCl}$ were analyzed) in which, during a sustained response to $5 \mu \mathrm{M} \mathrm{BPA}$, $100 \mu \mathrm{M} \mathrm{NiCl}_{2}$ and $10 \mu \mathrm{M}$ nifedipine, blockers, respectively, of T- and L-type VDCCs, were added to the medium. This protocol has been shown to block nearly all the calcium increase activated by chemical depolarization in these cells [40]. The combined blockers caused an average reduction of the $\left[\mathrm{Ca}^{2+}\right]_{\mathrm{i}}$ increase by $88.7 \%$ (Figure $4 b$ ).

a

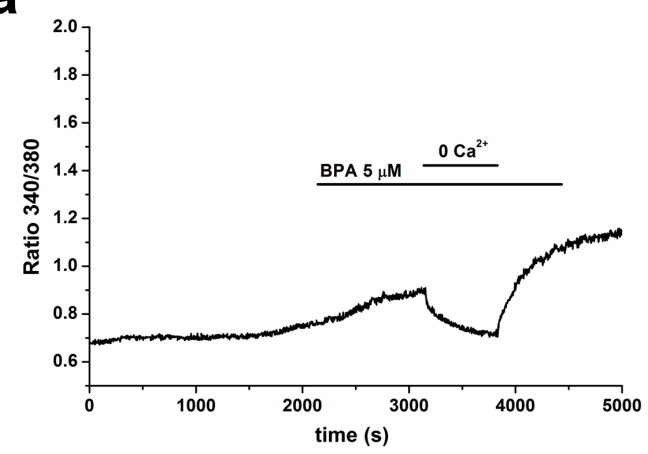

b

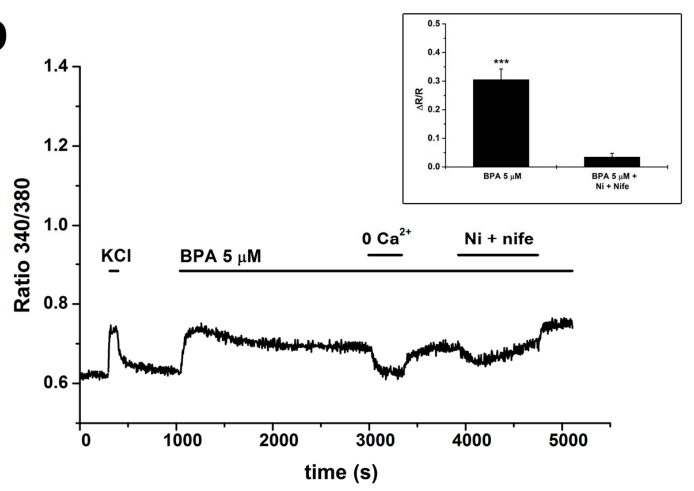

Figure 4. BPA-induced calcium signals are dependent on calcium influx, mainly through voltage-dependent channels. (a) Removal of calcium from the extracellular solution completely and reversibly abolished the $\left[\mathrm{Ca}^{2+}\right]_{\mathrm{i}}$ increase in response to $5 \mu \mathrm{M}$ BPA. (b) Addition of $100 \mu \mathrm{M} \mathrm{NiCl}_{2}$ and $10 \mu \mathrm{M}$ nifedipine strongly and reversibly reduced the $\left[\mathrm{Ca}^{2+}\right]_{\mathrm{i}}$ increase during perfusion with $5 \mu \mathrm{M}$ BPA. Inset: Response amplitudes during BPA administration with and without addition of blockers of voltage-operated calcium channels. Wilcoxon signed-rank test for paired samples; ${ }^{* * *} p<0.001$. 


\subsection{Changes in $\left[\mathrm{Ca}^{2+}\right]_{i}$ Induced by E2}

To understand the potential role of the perturbation of calcium homeostasis induced by BPA in GT1-7 cells, it is necessary to compare the responses to BPA with those to the physiological estrogen, estradiol (E2). E2 has been considered to exert mainly an excitatory action on GnRH neurons [41-44] and in some cases even an inhibitory one, depending on cell activity [41]. Regarding the modulation of calcium signaling in a model of migrating GnRH neurons from nasal explants, both stimulation [45] and inhibition [38] of calcium transients have been reported.

In GT1-7 cells, in $m=4$ experiments $10 \mathrm{nM}$ estradiol induced an increase in $\left[\mathrm{Ca}^{2+}\right]_{\mathrm{i}}$ in $72 \%$ of $n=$ 279 cells; $\Delta \mathrm{R} / \mathrm{R}$ was $0.12 \pm 0.01$ (Figure $5 \mathrm{a}$ ). When cells were subsequently stimulated with $100 \mathrm{nM}$ E2 (Figure $5 b$ ), an additional response was observed in $94 \%$ of $n=181$ cells; in this case $\Delta R / R$ was $0.56 \pm 0.04$, a value significantly higher than that obtained with the maximal dose of BPA (Figure $5 \mathrm{c}$ ). Interestingly, while in $10 \mathrm{nM}$ E2 the percentage of cells showing an oscillatory behavior was comparable to that observed with BPA (15\%), with $100 \mathrm{nM}$ E2 the percentage of cells showing marked oscillations in $\left[\mathrm{Ca}^{2+}\right]_{\mathrm{i}}$ was much higher, $77 \%$ (and the response lasted even after washout of the agonist).

a

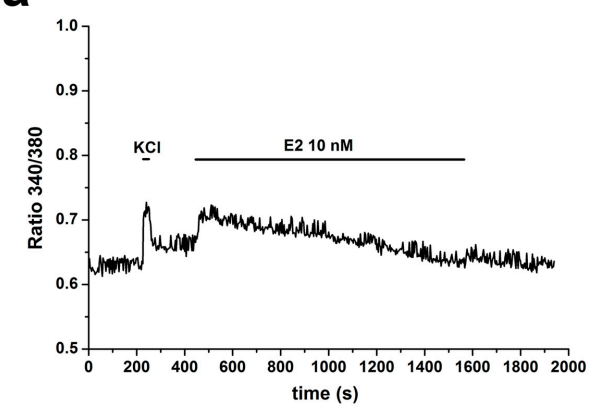

b

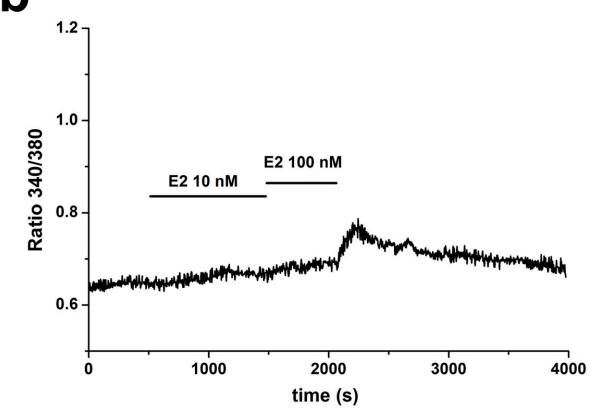

C

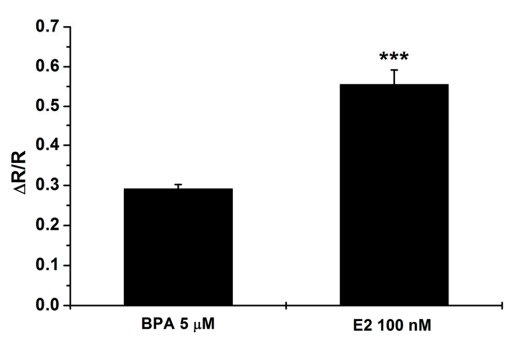

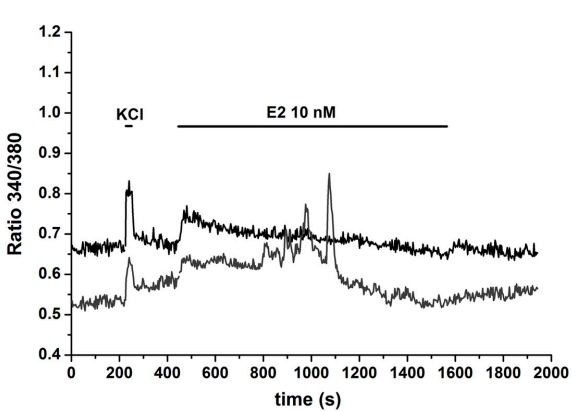

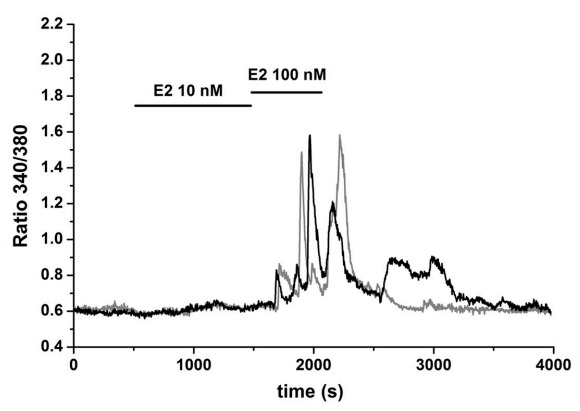

Figure 5. E2-induced increases in cytosolic calcium concentration. (a) Responses to $10 \mathrm{nM}$ E2: (left) averaged responses from a single experiment; and (right) examples of responses of individual cells. (b) Cells were challenged to incremental doses of E2 (10 and $100 \mathrm{nM})$ : (Left) averaged responses from a single experiment; and (Right) examples of responses of individual cells. (c) Comparison between the amplitudes of responses to $5 \mu \mathrm{M}$ BPA (same data as in Figure $3 b$ ) and to $100 \mathrm{nM}$ E2 ( $n=181$ cells). Mann-Whitney $U$-test; ${ }^{* * *} p<0.001$. 


\section{Discussion}

Environmental toxicants can affect the correct functioning of animal and human systems by interacting with different targets an interfering with a wide range of physiological processes. EDCs, in particular, are considered to exert their potentially adverse action by perturbing the endocrine system; among them BPA is one of the most widely investigated, based on its widespread use and its documented presence in human and animal fluids and tissues. The neuroendocrine axis is crucial for the correct growth, maturation and reproductive function in animals, but up to now has attracted only limited interest. The processes that can be affected at the cellular level cover a wide range, from differentiation and survival to electrical activity and hormone secretion; most of these are under the strict control of a critical parameter, the cytosolic calcium concentration, $\left[\mathrm{Ca}^{2+}\right]_{\mathrm{i}}$. Therefore, addressing this parameter can give relevant information about the pathways influenced by the molecule. Using a consolidated in vitro model on neuroendocrine cells, the GT1-7 cell line derived from mature mouse GnRH neurons [46], we have addressed the changes in $\left[\mathrm{Ca}^{2+}\right]_{\mathrm{i}}$ homeostasis induced by acute application of BPA. Due to the extremely wide range of concentrations that can be found in the literature, and to the fact that in many reports only one or two doses have been tested, we have chosen to use a relatively ample range of concentrations, in the interval considered to be compatible with BPA presence in animal and human organisms, based on epidemiological data, i.e., from $\mathrm{nM}$ to low $\mu \mathrm{M}$ concentrations.

We report that BPA, at all doses, does not affect cell survival and has a minor effect on cell proliferation. There are contrasting reports on BPA promoting cell proliferation [37] or apoptosis [35] in different experimental models, in many cases at high doses. In our case, the proliferative effect was statistically significant but of limited biological relevance. We also tested the potential effects of the molecule on GnRH expression, a key functional parameter in these cells. We found that at both the lower and higher dose employed in the present study, no significant changes in GnRH transcript levels could be detected; this finding is in accordance with data from other groups [23].

Most importantly, we found that the xenoestrogen induces changes in $\left[\mathrm{Ca}^{2+}\right]_{i}$ that, particularly in the lower range, can be partially abolished following washing. Both the number of responding cells and the amplitude of response are dose dependent. In a subpopulation of cells, BPA induced an oscillatory response.

The response could be totally suppressed by switching to a calcium-free extracellular solution, indicating that the changes in $\left[\mathrm{Ca}^{2+}\right]_{\mathrm{i}}$ are totally dependent from influx from the extracellular medium.

Several families of ionic channels have been reported to be modulated, either positively or negatively, by BPA (for a recent and comprehensive review, see [32]). The data on calcium-permeable channels and neuronal cells are quite limited, and in some cases related to high BPA doses. GT1-7 cells are endowed with a rich array of calcium channels, both receptor- and voltage-operated; as for the latter, the tests performed in our experiments showing that chemical depolarization induces in most cells an increase in $\left[\mathrm{Ca}^{2+}\right]_{i}$ provide evidence for a considerable expression of this family of channels. The finding that block of VDCCs abolished most of the response to BPA points to a major involvement of this family of channels in the changes in $\left[\mathrm{Ca}^{2+}\right]_{i}$ induced by the xenoestrogen. VDCCs may be the direct target of the transduction pathways triggered by BPA, or open following the activation of other classes of depolarizing cationic channels.

Only two papers are available on BPA and neuronal voltage-dependent calcium channels, reporting conflicting results: one reporting an inhibitory effect in mouse DRG neurons [34], and another one about stimulation of neurotransmitter release dependent on VDCCs in PC12 cells [47]. It must be observed that both studies used very high doses, such as $100 \mu \mathrm{M}$ and above.

It has been reported [38] that BPA reduces the spontaneous calcium spiking activity in GnRH neurons migrating from mouse nasal explants, and compared this effect with that of $10 \mathrm{nM}$ E2, which they found also to be inhibitory. These data, obtained from a primary model of developing GnRH neurons, deserve a detailed comment. First, the Authors used neurons that showed spontaneous calcium signals. In our hands, GT1-7 cells only occasionally showed calcium spikes in basal conditions. It must be noted that, according to [41], E2 increases activity of primary GnRH neurons that are basally 
silent, while has an inhibitory effect on basally active neurons. Moreover, an excitatory effect of E2 (2-200 nM) has been described [45] in the same preparation as used in [38]. Finally, and of greater relevance in the present context, most of the data in [38] have been obtained from neurons stimulated with $50 \mu \mathrm{M}$ BPA. Again, this is a quite high dose, about two orders of magnitude above the lowest observed adverse effect level (LOAEL) that, for in vitro experiments, has been calculated to be about $0.2 \mu \mathrm{M}$ [48]. Therefore, the relevance of these findings may be dependent on the experimental model and, more significantly, may be limited by the high dose employed.

Since no data are available on the effects on calcium homeostasis exerted by E2 in GT1-7 cells, we compared the responses to BPA with those induced by the physiological estrogen. We report that $\mathrm{E} 2$, in the nanomolar range $(10-100 \mathrm{nM})$, induced $\left[\mathrm{Ca}^{2+}\right]_{\mathrm{i}}$ increases comparable to those elicited by $\mathrm{BPA}$, even if the amplitude with $100 \mathrm{nM}$ E2 was significantly higher than with $5 \mu \mathrm{M}$ BPA. Moreover, with $100 \mathrm{nM} \mathrm{E2}$, a marked increase in the oscillatory behavior and in the duration of the responses was observed.

In conclusion, we provide the first evidence that, in a consolidated model of neuroendocrine cells, environmentally relevant doses of BPA can induce perturbation of intracellular calcium homeostasis; these changes are of moderate amplitude and, except for the higher dose, reversible after washing. Over about three orders of magnitude, the increase in peak amplitude of the responses was about twofold, and well below the amplitude of the signals induced by $100 \mathrm{nM} \mathrm{E2}$. It should be noted that even subtle changes in calcium homeostasis can have significant functional consequences, such as changing the levels of cellular excitability and activation of intracellular enzymes. However, further investigations are needed to elucidate the differences in the signaling pathways and the biological outcomes implied by the different responses induced by BPA and E2 in terms of both signal amplitude and oscillatory behavior.

\section{Materials and Methods}

\subsection{Materials}

Unless otherwise specified, materials were obtained from Sigma-Aldrich (St. Louis, MO, USA).

\subsection{Cell Culture}

GT1-7 cells, an immortalized line derived from highly differentiated mouse GnRH neurons (generously donated by Prof. P.L. Mellon, Department of Obstetrics, Gynecology, and Reproductive Sciences, Center for Reproductive Science and Medicine, University of California San Diego, La Jolla, CA, USA), were maintained in Dulbecco's Modified Eagle's Medium (DMEM) supplemented with $10 \%$ heat-inactivated fetal bovine serum (FBS, Lonza, Basel, Switzerland), gentamycin $(50 \mu \mathrm{g} / \mathrm{mL}$ ), and glutamine $(2 \mathrm{mM})$ at $37{ }^{\circ} \mathrm{C}$, in a humidified atmosphere of $5 \% \mathrm{CO}_{2}$ in air. BPA and E2 were dissolved in DMSO prior to dilution in media.

\subsection{Survival and Proliferation Assays}

For proliferation assays, GT1-7 neuronal cells were plated in 96-well plates in DMEM containing $10 \%$ FBS at a density of 40,000 cells/ $\mathrm{cm}^{2}$ (Falcon, Becton Dickinson, Franklin Lakes, NJ, USA) and maintained in DMEM with 10\% FBS. After $24 \mathrm{~h}$, the medium was replaced with DMEM plus 10\% FBS with or without different concentrations of BPA for further 24 or $72 \mathrm{~h}$.

For survival assays, after one day in $10 \%$ FBS, the medium was switched to one containing $0.5 \%$ FBS, to promote survival without interference with proliferative effects; different concentrations of BPA were added for $24 \mathrm{~h}$.

After the treatments, cells were fixed in $2.5 \%$ glutaraldehyde in PBS, stained with crystal violet $(0.1 \%$ in $20 \%$ methanol), solubilized in acetic acid $(10 \%, v / v)$ and read at $595 \mathrm{~nm}$ in a Microplate Reader (model 550, Bio-Rad Laboratories, Hercules, CA, USA). 
Data (total cell number normalized to control) were expressed as mean \pm standard error of the mean (SEM). Three independent experiments (each performed in 6 technical replicates) for each condition were carried out.

\subsection{GnRH Expression Analysis}

GT1-7 neuronal cells were plated in $60 \mathrm{~mm}$ tissue culture dishes (Falcon, Becton Dickinson, Franklin Lakes, NJ, USA) in DMEM containing 10\% FBS at a density of 40,000 cells $/ \mathrm{cm}^{2}$. After $24 \mathrm{~h}$, the medium was replaced with DMEM plus 10\% FBS with or without BPA $10 \mathrm{nM}$ or $5 \mu \mathrm{M}$ for further $72 \mathrm{~h}$; three independent replicates were set for each condition. Total RNA was isolated from control and treated GT1-7 cells using Tri-Reagent (Sigma, St. Louis, MO, USA) and following manufacturer guidelines. qReal-Time PCR was performed using SensiFAST SYBR No-ROX kit (Bioline, London, UK) and the thermal cycler Rotor Gene Q (Qiagen, Hilden, Germany). Primers were designed with Primer-BLAST software (NCBI, National Center for Biotechnology Information, U.S. National Library of Medicine, Bethesda, MD, USA) and were as follows: GnRH Sense 5' ${ }^{\prime}$ TCTTGATGTCCCTTAGAGTGG-3', Reverse 5'-GCCCATCTCTTGGAAAGACT-3'; $\beta$-actin Sense 5'-TCTTTGCAGCTCCTTCGTTG-3', Reverse $5^{\prime}$-ACGATGGAGGGGAATACAGC-3'. Each sample was analyzed in three technical replicates containing $50 \mathrm{ng}$ of total RNA. The relative quantification of gene expression was done using a standard curve that was built by pooling all the RNA samples and making serial dilutions (range: 200-6.25 ng of total RNA). The amplicon concentrations were expressed in arbitrary units and were normalized for the expression of $\beta$-actin, a commonly used housekeeping gene. GnRH mRNA expression of BPA-treated cells was reported as average fold changes relative to the expression of control (DMSO treated) cells; controls were assigned a value of 1 .

\subsection{Calcium Imaging}

For ratiometric measurements of $\left[\mathrm{Ca}^{2+}\right]_{\mathrm{i}}$ GT1-7 cells were plated on glass cover-slips (32 mm diameter) coated with poly-L-lysine $(100 \mu \mathrm{g} / \mathrm{mL})$ at densities of 10,000 cells $/ \mathrm{cm}^{2}$. The cells were maintained in DMEM supplemented with $10 \%$ FBS, gentamycin $(50 \mu \mathrm{g} / \mathrm{mL})$, and $2 \mathrm{mM}$ glutamine at $37^{\circ} \mathrm{C}$, in a humidified atmosphere of $5 \% \mathrm{CO}_{2}$ in air and then switched for $4-5$ days to $0.5 \%$ FBS supplemented with B27 (Invitrogen, Carlsbad, CA, USA), to improve survival and differentiation. Calcium imaging technique, protocols and instrumentation were as previously described [49]. Briefly, cells were loaded with the Fura- 2 acetoxymethyl ester $\left(2.5 \mu \mathrm{M}, 45 \mathrm{~min}, 37^{\circ} \mathrm{C}\right)$ and subsequently shifted to a standard physiological Tyrode solution of the following composition (in $\mathrm{mM}$ ): $\mathrm{NaCl}, 154$; $\mathrm{KCl}, 4 ; \mathrm{CaCl}_{2}, 2 ; \mathrm{MgCl}_{2}, 1$; 4-(2-hydroxyethyl)-1-piperazineethanesulfonic acid (HEPES), 5; glucose, 5.5; and $\mathrm{NaOH}$ ( $\mathrm{pH}$ 7.35). Agonists of interest (i.e., BPA and E2) were dissolved in the Tyrode solution at the required concentrations. Resulting solutions were applied with a microperfusion system; for calcium-free conditions, the $\mathrm{CaCl}_{2}$ salt was omitted and the calcium chelator ethylene glycol tetraacetic acid (EGTA; $0.5 \mathrm{mM}$ ) was added. Cells were imaged every $3 \mathrm{~s}$ at $37^{\circ} \mathrm{C}$ using a monochromator system attached to a Nikon inverted microscope with a 20× objective (Nikon S Fluor). Images were acquired using an enhanced CCD camera (Roper Scientific/Photometrics, Martinsried, Germany) and the Metafluor software (Universal Imaging Co., West Chester, PA, USA). Calcium signals in response to the different stimuli were measured as peak amplitude in terms of increment in the ratiometric fluorescent emission $(\Delta R)$, relative to its basal value $(R)$.

Before application of either BPA or E2, cells were challenged with a Tyrode solution containing $40 \mathrm{mM} \mathrm{KCl}$, to depolarize cells and elicit calcium influx trough voltage-dependent channels, as a test of cell viability.

\subsection{Statistical Analysis}

Mean and standard error of the mean (SEM) were used as measures of central tendency and dispersion, respectively. All samples were first tested for normality (Shapiro-Wilk test) and for homogeneity of variance (Levene's test). When possible, statistical significance was assessed by 
parametric tests ( $t$-test or one-way ANOVA and Dunnett's post hoc test), otherwise non-parametric alternatives were used, as detailed in the text. Unless otherwise specified, all statistical tests were among unpaired samples, two-tailed and a $p$-value $<0.05$ was considered statistically significant.

Author Contributions: Conceptualization, F.A.R., D.L. and P.B.; Methodology, A.G., F.A.R. and E.C.; Formal Analysis, F.A.R.; Investigation, A.G., F.A.R., E.C. and V.S.; Writing-Original Draft Preparation, D.L. and F.A.R.; Writing-Review and Editing, P.B. and A.G.; Visualization, A.G.; Supervision, D.L.; Project Administration, D.L.; and Funding Acquisition, P.B.

Funding: This research was partially financed by Project PRIN \#2010W87LBJ_005 to P.B.

Conflicts of Interest: The authors declare no conflict of interest.

\section{References}

1. Matthews, J.B.; Twomey, K.; Zacharewski, T.R. In vitro and in vivo interactions of bisphenol A and its metabolite, bisphenol A glucuronide, with estrogen receptors alpha and beta. Chem. Res. Toxicol. 2001, 14, 149-157. [CrossRef]

2. Welshons, W.V.; Nagel, S.C.; vom Saal, F.S. Large effects from small exposures. III. Endocrine mechanisms mediating effects of bisphenol A at levels of human exposure. Endocrinology 2006, 147, S56-S69. [CrossRef]

3. Calafat, A.M.; Ye, X.; Wong, L.Y.; Reidy, J.A.; Needham, L.L. Exposure of the U.S. population to bisphenol A and 4-tertiary-octylphenol: 2003-2004. Environ. Health Perspect. 2008, 116, 39-44. [CrossRef]

4. Shelnutt, S.; Kind, J.; Allaben, W. Bisphenol A: Update on newly developed data and ho w they address NTP's 2008 finding of "Some Concern". Food Chem. Toxicol. 2013, 57, 284-295. [CrossRef]

5. Hines, E.P.; Mendola, P.; von Ehrenstein, O.S.; Ye, X.; Calafat, A.M.; Fenton, S.E. Concentrations of environmental phenols and parabens in milk, urine and serum of lactating North Carolina women. Reprod. Toxicol. 2014, 54, 120-128. [CrossRef]

6. Vom Saal, F.S.; Akingbemi, B.T.; Belcher, S.M.; Birnbaum, L.S.; Crain, D.A.; Eriksen, M.; Farabollini, F.; Guillette, L.J., Jr.; Hauser, R.; Heindel, J.J.; et al. Chapel Hill bisphenol A expert panel consensus statement: Integration of mechanisms, effects in animals and potential to impact human health at current levels of exposure. Reprod. Toxicol. 2007, 24, 131-138. [CrossRef] [PubMed]

7. Vandenberg, L.N.; Hunt, P.A.; Myers, J.P.; Vom Saal, F.S. Human exposures to bisphenol A: Mismatches between data and assumptions. Rev. Environ. Health 2013, 28, 37-58. [CrossRef] [PubMed]

8. Rochester, J.R. Bisphenol A and human health: A review of the literature. Reprod. Toxicol. 2013, 42, $132-155$. [CrossRef] [PubMed]

9. Ye, B.S.; Leung, A.O.W.; Wong, M.H. The association of environmental toxicants and autism spectrum disorders in children. Environ. Pollut. 2017, 227, 234-242. [CrossRef] [PubMed]

10. Meeker, J.D. Exposure to environmental endocrine disrupting compounds and men's health. Maturitas 2010, 66, 236-241. [CrossRef]

11. Braun, J.M.; Hauser, R. Bisphenol A and children's health. Curr. Opin. Pediatr. 2011, 23, 233-239. [CrossRef] [PubMed]

12. Inadera, H. Neurological Effects of Bisphenol A and its Analogues. Int. J. Med. Sci. 2015, 12, 926-936. [CrossRef] [PubMed]

13. Braun, J.M. Early-life exposure to EDCs: Role in childhood obesity and neurodevelopment. Nat. Rev. Endocrinol. 2017, 13, 161-173. [CrossRef] [PubMed]

14. Hajszan, T.; Leranth, C. Bisphenol A interferes with synaptic remodeling. Front. Neuroendocrinol. 2010, 31, 519-530. [CrossRef] [PubMed]

15. Kimura, E.; Matsuyoshi, C.; Miyazaki, W.; Benner, S.; Hosokawa, M.; Yokoyama, K.; Kakeyama, M.; Tohyama, C. Prenatal exposure to bisphenol A impacts neuronal morphology in the hippocampal CA1 region in developing and aged mice. Arch. Toxicol. 2016, 90, 691-700. [CrossRef] [PubMed]

16. Ling, W.; Endo, T.; Kubo, K.; Nakajima, K.; Kakeyama, M.; Tohyama, C. In Utero Bisphenol A Exposure Induces Abnormal Neuronal Migration in the Cerebral Cortex of Mice. Front. Endocrinol. 2016, 7, 7. [CrossRef] 
17. Liu, Z.H.; Ding, J.J.; Yang, Q.Q.; Song, H.Z.; Chen, X.T.; Xu, Y.; Xiao, G.R.; Wang, H.L. Early developmental bisphenol-A exposure sex-independently impairs spatial memory by remodeling hippocampal dendritic architecture and synaptic transmission in rats. Sci. Rep. 2016, 6, 32492. [CrossRef]

18. Hu, F.; Li, T.; Gong, H.; Chen, Z.; Jin, Y.; Xu, G.; Wang, M. Bisphenol A Impairs Synaptic Plasticity by Both Pre- and Postsynaptic Mechanisms. Adv. Sci. (Weinh) 2017, 4, 1600493. [CrossRef]

19. Inagaki, T.; Smith, N.; Lee, E.K.; Ramakrishnan, S. Low dose exposure to Bisphenol A alters development of gonadotropin-releasing hormone 3 neurons and larval locomotor behavior in Japanese Medaka. Neurotoxicology 2016, 52, 188-197. [CrossRef]

20. Xu, G.; Hu, F.; Wang, X.; Zhang, B.; Zhou, Y. Bisphenol A exposure perturbs visual function of adult cats by remodeling the neuronal activity in the primary visual pathway. Arch. Toxicol. 2018, 92, 455-468. [CrossRef]

21. Elsworth, J.D.; Jentsch, J.D.; Groman, S.M.; Roth, R.H.; Redmond, E.D., Jr.; Leranth, C. Low circulating levels of bisphenol-A induce cognitive deficits and loss of asymmetric spine synapses in dorsolateral prefrontal cortex and hippocampus of adult male monkeys. J. Comp. Neurol. 2015, 523, 1248-1257. [CrossRef] [PubMed]

22. Huang, B.; Ning, S.; Zhang, Q.; Chen, A.; Jiang, C.; Cui, Y.; Hu, J.; Li, H.; Fan, G.; Qin, L.; et al. Bisphenol A Represses Dopaminergic Neuron Differentiation from Human Embryonic Stem Cells through Downregulating the Expression of Insulin-like Growth Factor 1. Mol. Neurobiol. 2016, 54, 3798-3812. [CrossRef] [PubMed]

23. Mueller, J.K.; Heger, S. Endocrine disrupting chemicals affect the gonadotropin releasing hormone neuronal network. Reprod. Toxicol. 2014, 44, 73-84. [CrossRef] [PubMed]

24. Babu, S.; Uppu, S.; Claville, M.O.; Uppu, R.M. Prooxidant actions of bisphenol A (BPA) phenoxyl radicals: Implications to BPA-related oxidative stress and toxicity. Toxicol. Mech. Methods 2013, 23, 273-280. [CrossRef] [PubMed]

25. Franssen, D.; Gérard, A.; Hennuy, B.; Donneau, A.F.; Bourguignon, J.P.; Parent, A.S. Delayed Neuroendocrine Sexual Maturation in Female Rats After a Very Low Dose of Bisphenol A Through Altered GABAergic Neurotransmission and Opposing Effects of a High Dose. Endocrinology 2016, 157, 1740-1750. [CrossRef]

26. Heindel, J.J.; Newbold, R.R.; Bucher, J.R.; Camacho, L.; Delclos, K.B.; Lewis, S.M.; Vanlandingham, M.; Churchwell, M.I.; Twaddle, N.C.; McLellen, M.; et al. NIEHS/FDA CLARITY-BPA research program update. Reprod. Toxicol. 2015, 58, 33-44. [CrossRef]

27. Patisaul, H.B.; Todd, K.L.; Mickens, J.A.; Adewale, H.B. Impact of neonatal exposure to the ERalpha agonist PPT, bisphenol-A or phytoestrogens on hypothalamic kisspeptin fiber density in male and female rats. Neurotoxicology 2009, 30, 350-357. [CrossRef]

28. Bai, Y.; Chang, F.; Zhou, R.; Jin, P.P.; Matsumoto, H.; Sokabe, M.; Chen, L. Increase of anteroventral periventricular kisspeptin neurons and generation of E2-induced LH-surge system in male rats exposed perinatally to environmental dose of bisphenol-A. Endocrinology 2011, 152, 1562-1571. [CrossRef] [PubMed]

29. Wang, X.; Chang, F.; Bai, Y.; Chen, F.; Zhang, J.; Chen, L. Bisphenol A enhances kisspeptin neurons in anteroventral periventricular nucleus of female mice. J. Endocrinol. 2014, 221, 201-213. [CrossRef]

30. Naulé, L.; Picot, M.; Martini, M.; Parmentier, C.; Hardin-Pouzet, H.; Keller, M.; Franceschini, I.; Mhaouty-Kodja, S. Neuroendocrine and behavioral effects of maternal exposure to oral bisphenol A in female mice. J. Endocrinol. 2014, 220, 375-388. [CrossRef] [PubMed]

31. Adewale, H.B.; Jefferson, W.N.; Newbold, R.R.; Patisaul, H.B. Neonatal bisphenol-a exposure alters rat reproductive development and ovarian morphology without impairing activation of gonadotropin-releasing hormone neurons. Biol. Reprod. 2009, 81, 690-699. [CrossRef]

32. Soriano, S.; Ripoll, C.; Alonso-Magdalena, P.; Fuentes, E.; Quesada, I.; Nadal, A.; Martinez-Pinna, J. Effects of Bisphenol A on ion channels: Experimental evidence and molecular mechanisms. Steroids 2016, 111, 12-20. [CrossRef]

33. Kuo, C.C.; Huang, J.K.; Chou, C.T.; Cheng, J.S.; Tsai, J.Y.; Fang, Y.C.; Hsu, S.S.; Liao, W.C.; Chang, H.T.; Ho, C.M.; et al. Effect of bisphenol A on $\mathrm{Ca}(2+)$ fluxes and viability in Madin-Darby canine renal tubular cells. Drug Chem. Toxicol. 2011, 34, 454-461. [CrossRef]

34. Deutschmann, A.; Hans, M.; Meyer, R.; Häberlein, H.; Swandulla, D. Bisphenol A inhibits voltage-activated $\mathrm{Ca}(2+)$ channels in vitro: Mechanisms and structural requirements. Mol. Pharmacol. 2013, 83, 501-511. [CrossRef] 
35. Lee, S.; Suk, K.; Kim, I.K.; Jang, I.S.; Park, J.W.; Johnson, V.J.; Kwon, T.K.; Choi, B.J.; Kim, S.H. Signaling pathways of bisphenol A-induced apoptosis in hippocampal neuronal cells: Role of calcium-induced reactive oxygen species, mitogen-activated protein kinases, and nuclear factor-kappaB. J. Neurosci. Res. 2008, 86, 2932-2942. [CrossRef]

36. Tanabe, N.; Kimoto, T.; Kawato, S. Rapid Ca(2+) signaling induced by Bisphenol A in cultured rat hippocampal neurons. Neuro Endocrinol. Lett. 2006, 27, 97-104.

37. Kochukov, M.Y.; Jeng, Y.J.; Watson, C.S. Alkylphenol xenoestrogens with varying carbon chain lengths differentially and potently activate signaling and functional responses in GH3/B6/F10 somatomammotropes. Environ. Health Perspect. 2009, 117, 723-730. [CrossRef] [PubMed]

38. Klenke, U.; Constantin, S.; Wray, S. BPA Directly Decreases GnRH Neuronal Activity via Noncanonical Pathway. Endocrinology 2016, 157, 1980-1990. [CrossRef] [PubMed]

39. Steinmetz, R.; Brown, N.G.; Allen, D.L.; Bigsby, R.M.; Ben-Jonathan, N. The environmental estrogen bisphenol A stimulates prolactin release in vitro and in vivo. Endocrinology 1997, 138, 1780-1787. [CrossRef] [PubMed]

40. Gilardino, A.; Catalano, F.; Ruffinatti, F.A.; Alberto, G.; Nilius, B.; Antoniotti, S.; Martra, G.; Lovisolo, D. Interaction of $\mathrm{SiO}_{2}$ nanoparticles with neuronal cells: Ionic mechanisms involved in the perturbation of calcium homeostasis. Int. J. Biochem. Cell Biol. 2015, 66, 101-111. [CrossRef] [PubMed]

41. Romanò, N.; Herbison, A.E. Activity-dependent modulation of gonadotrophin-releasing hormone neurone activity by acute oestradiol. J. Neuroendocrinol. 2012, 24, 1296-1303. [CrossRef]

42. Rønnekleiv, O.K.; Bosch, M.A.; Zhang, C. 17 $\beta$-oestradiol regulation of gonadotrophin-releasing hormone neuronal excitability. J. Neuroendocrinol. 2012, 24, 122-130. [CrossRef]

43. Rønnekleiv, O.K.; Zhang, C.; Bosch, M.A.; Kelly, M.J. Kisspeptin and Gonadotropin-Releasing Hormone Neuronal Excitability: Molecular Mechanisms Driven by $17 \beta$-Estradiol. Neuroendocrinology 2015, 102, 184-193. [CrossRef]

44. Terasawa, E.; Kenealy, B.P. Neuroestrogen, rapid action of estradiol, and GnRH neurons. Front. Neuroendocrinol. 2012, 33, 364-375. [CrossRef] [PubMed]

45. Temple, J.L.; Laing, E.; Sunder, A.; Wray, S. Direct action of estradiol on gonadotropin-releasing hormone-1 neuronal activity via a transcription-dependent mechanism. J. Neurosci. 2004, 24, 6326-6333. [CrossRef] [PubMed]

46. Mellon, P.L.; Windle, J.J.; Goldsmith, P.C.; Padula, C.A.; Roberts, J.L.; Weiner, R.I. Immortalization of hypothalamic GnRH neurons by genetically targeted tumorigenesis. Neuron 1990, 5, 1-10. [CrossRef]

47. Yoneda, T.; Hiroi, T.; Osada, M.; Asada, A.; Funae, Y. Non-genomic modulation of dopamine release by bisphenol-A in PC12 cells. J. Neurochem. 2003, 87, 1499-1508. [CrossRef]

48. Wetherill, Y.B.; Akingbemi, B.T.; Kanno, J.; McLachlan, J.A.; Nadal, A.; Sonnenschein, C.; Watson, C.S.; Zoeller, R.T.; Belcher, S.M. In vitro molecular mechanisms of bisphenol A action. Reprod. Toxicol. 2007, 24, 178-198. [CrossRef] [PubMed]

49. Ruffinatti, F.A.; Gilardino, A.; Lovisolo, D.; Ferraro, M. Spatial wavelet analysis of calcium oscillations in developing neurons. PLoS ONE 2013, 8, e75986. [CrossRef] [PubMed]

(C) 2019 by the authors. Licensee MDPI, Basel, Switzerland. This article is an open access article distributed under the terms and conditions of the Creative Commons Attribution (CC BY) license (http://creativecommons.org/licenses/by/4.0/). 